\title{
EU Aid for Fighting Corruption in the Czech Republic and Slovakia: Where Did It Go Wrong?
}

\author{
Eline De Ridder
}

\begin{abstract}
During the Eastern enlargement process of the European Union (EU), the Central and Eastern European Countries (CEECs) were supported by the Union in terms of combating corruption issues. This was seen as a key step in their transformation towards liberal democracy and eventual accession to the EU.

This article questions the extent of influence which the EU has had in terms of dealing with problems of corruption in the Czech Republic and Slovakia, both during and after their accession to the Union. It is noted that during the accession process the EU utilised a number of instruments to support accession states, such as the Czech Republic and Slovakia, fight corruption. Regardless of these incentives, the corruption records of both countries improved little by the time they acceded to the EU in 2004 and continues to be problematic in the post-accession era. It is suggested in this article that several dynamics, such as the absence of a clear and consistent policy from the EU and the importance of domestic politics in the acceding countries, help to explain why the fight against corruption in these two central European states has been and continues to be so weak.
\end{abstract}

IN MAY 2004 EIGHT CENTRAL AND EASTERN EUROPEAN COUNTRIES (CEECs) JOINED the European Union (EU). In the years before EU accession their societal, political and economic structures underwent considerable changes, in part guided by the prospect of EU membership. By linking accession to the Union with the fulfillment of certain criteria (conditionality), the EU tried to support the CEECs in their transition to liberal democracy. ${ }^{1}$

During the enlargement process the EU applied the concept of conditionality to support the consolidation of democracy in Central and Eastern Europe (CEE). In 1993 the European Council at its meeting in Copenhagen approved the criteria of formal democracy which had to be fulfilled in order to achieve membership. In the years which followed the European Commission, which had been charged with overseeing the accession process, elaborated the concept of democratic conditionality, to include criteria of substantive democracy. ${ }^{2}$ Corruption was one of the domains of deeper democracy in which the EU tried to bring about change. However, despite including

\footnotetext{
${ }^{1}$ For a comprehensive overview of the motivations behind the Eastern enlargement process, see De Ridder et al. 2008.

${ }^{2}$ According to Kaldor and Vejvoda (1997) the process of democratic consolidation can be split up in two major levels: the formal level of democracy and the substantive level. The first implies the institutionalisation of democratic rules and procedures, which leads to the dissemination of new democratic rules, institutions, procedures and laws. Substantive democracy then concerns the practical implementation of formal democracy. It implies the deep entrenchment of democracy in a society, making democracy to endure as "the only game in town" (Linz and Stepan 1996: 5).
} 
corruption as a point of interest in the accession process, the EU has not been able to bring about radical changes in the corruption records of the CEECs.

In this article, a number of dynamics of the Eastern enlargement process, which explain the limited impact of the Union's support for fighting corruption in the candidate countries, are examined. The research which informs the article focuses on the accession process of two CEECs - the Czech Republic and Slovakia. After a short elaboration on the state of corruption in $\mathrm{CEE}$, an examination of how the EU has handled the topic of corruption in the accession process of both countries is undertaken. An analysis is also presented of the EU's principle tools of influence (Regular Reports, Short and Medium Term Priorities and Objectives, and PHARE financial aid projects), with regard to fighting corruption.

In the following section an examination of which elements most effectively explain the limited impact of the EU in the domain of fighting corruption is provided. The first part focuses on aspects of the Unions enlargement policy and how the lack of clear anticorruption criteria as well as the absence of a consistent anti-corruption framework in the EU have tempered the Union's success in triggering changes in the Czech and Slovak corruption records. In the second part, the importance of national politics on the democratic consolidation process is elaborated. For example, the Czech and Slovak policies on fighting corruption have determined to a considerable degree the development of corruption evident within these states throughout their EU accession timeframe. After identifying the elements which have restricted the EU's impact on corruption, a cautious assessment of the scope left for the EU to influence the substantive democracy records of its candidate states is presented.

\section{Corruption in Central and Eastern Europe}

Corruption - generally described as "the abuse of public roles and resources for private benefit" (Johnston 1986: 459; 2000: 5; Appel 2001: 529; Krastev 2004a) - harms the economic and political interests of a country. Several studies have identified the negative economic effects of corruption (Tanzi and Davoodi 1997; Lízal and Kočenda 2000 and 2001; Johnston 2000). Equally devastating however are the effects of corruption on the political level. Corruption constitutes an attack on the democracy of a state by inflicting damage upon several basic principles of democratic rule. (Appel 2001: 547-552; Lederman et al. 2001: 5; Schedler et al. 1999: 14). Fighting corruption has therefore been accepted as a precondition to build a stable substantive democracy (Johnston 2000; Lederman et al. 2001).

Several studies point to the existence of a relatively high level of corruption in CEE (Mamedova 2002; Grigorescu 2006; Krastev 2004a; Open Society Institute 2002). The findings of these studies are supported by the data of indices measuring corruption worldwide. The most frequently used data-set on corruption is provided by Transparency International (TI). Since 1994 the civil society organisation has drawn up a ranking of different countries based on their perceived level of corruption. The TI Corruption Perception Index is based on data sources measuring the overall extent of corruption in the public and political sectors (Transparency International 2007). Each country in the index is assigned a value between 0 and 10. The lower the level of corruption, the higher the value assigned.

A second data-set on corruption is offered by the World Bank. Its 'Worldwide Governance Indicators' research project provides data on six aggregate governance indicators on 212 countries and territories, covering the years 1996 to 2006. One of the governance dimensions included in the study is control of corruption, which measures "the extent to which public power is exercised for private gain, including petty and grand forms of corruption, as well as 'capture' of the state by elites and private interests" (Kaufmann et al. 2008: 10-11). Each country is assigned a percentile rank, 
which indicates the percentage of countries worldwide that rate below the selected country. Higher values thus indicate better governance ratings (World Bank 2008a and 2008b).

When comparing the average value for the 'Old Europe' with the average of the CEECs, the rankings of both Transparency International and the World Bank indicate that the CEECs face higher levels of corruption than the EU-15.

Graph 1: Corruption in CEE and EU-15, based on Transparency International data

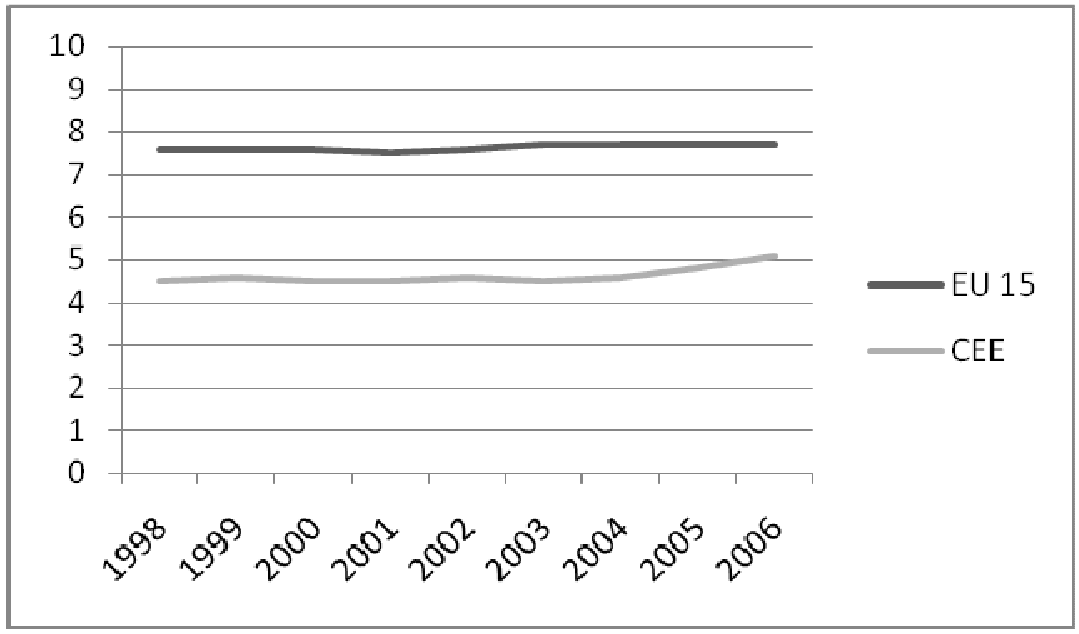

Graph 2: Corruption in CEE and EU-15, based on World Bank data

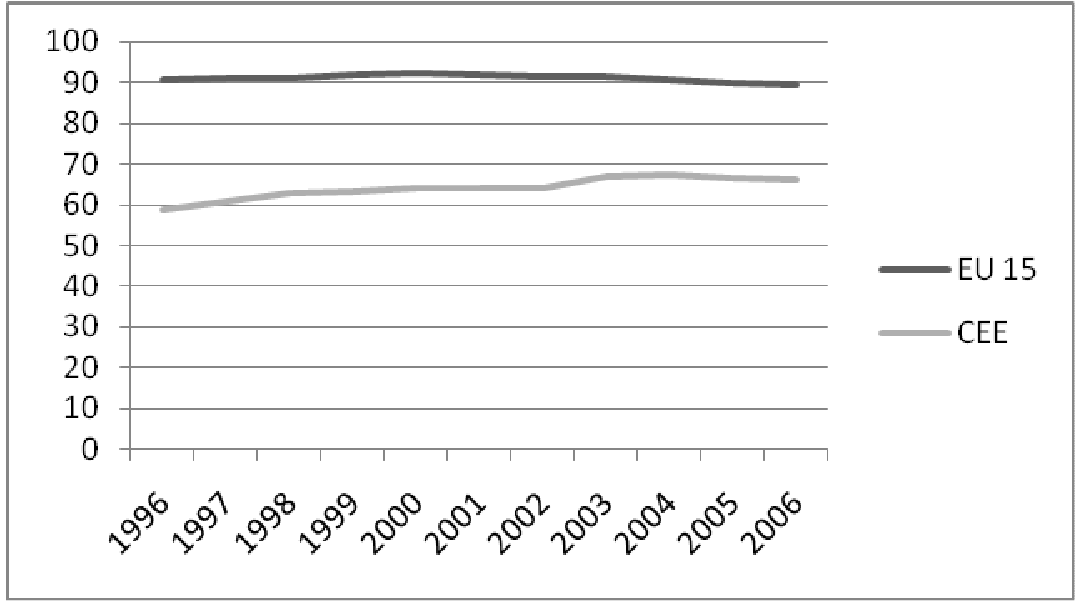

It is important to note that both indices report on the perception of corruption and do not claim to reflect the actual level of corruption occurring in a country. The concealed nature of corruption makes it practically impossible to measure objectively the actual level of corruption. For this reason academics as well as policy makers resort to perceptions of corruption as a reflection of the actual state of affairs.

A third data-set on corruption is provided by Freedom House. Its 'Nations in Transit' study analyses the progress of democratic change in 29 countries. Data is provided on seven democratic categories, including corruption. Numeric ratings are assigned based on a scale of 1 to 7 , with 1 representing the highest and 7 the lowest level of democratic progress. Since the 'Nations in Transit' study focuses on reform in the former communist states of Europe and Eurasia, it does not include the countries of the EU-15. Therefore a comparison between the Old and New Europe, based on the data 
offered by Freedom House, is not included in this study. The data-set is used however, when assessing the development of corruption in the Czech Republic and Slovakia during EU accession (see below). In addition to Transparency International, the World Bank and Freedom House, other data sources on corruption can be found. They have however not been included in this article for reasons of countries covered and/or data accessibility.

\section{Corruption in the Czech Republic and Slovakia}

The Czech Republic and Slovakia are two CEECs challenged by relatively high levels of corruption. Since their independence corruption cases at different levels of governance have seized the attention of society in both states. In the Czech Republic several ministers had to leave the government due to corruption scandals. The most prominent was the resignation in July 1999 of the Minister of Finance, Ivo Svoboda, who faced charges of fraud related to the privatisation process (Allnutt et al. 2001: 130; Brokl and Mansfeldová 2000: 356). The Czech Republic has been hit more than once by corruption cases at the highest level of governance. At the end of 1997 the Czech Government of Prime Minister Václav Klaus was brought down as a result of financial scandals involving the senior coalition party, the Civic Democratic Party (Občanská demokratická strana - ODS). In 2005 a second Czech government collapsed on allegations of corruption, when on 25 April 2005 Prime Minister Stanislav Gross handed in his resignation, and thus that of the entire Czech government, after being unable to explain the origin of funds for the purchase of his apartment (Horáková 2005). Also the last Czech government was plagued by a high-level corruption scandal, involving Jiři Čunek - leader of the coalition party, the Christian and Democratic Union-Czechoslovak People's Party (Křest'anka a demokratická unie-Československá strana lidová - KDU-ČSL). Although the investigation into the corruption allegations was suddenly dropped, lots of questions remain unanswered (Richter 2007). This makes the Čunek-case a matter of controversy which divided the Topolánek government.

Slovakia has known similar high-level corruption cases in the years following its independence. In 1996 one of the biggest corruption scandals in Slovak history came to light. The case involved the ministers of agriculture and economy, leading to the dismissal of the latter (Ján Ducký) in August 1996 (Malová 1997: 483). Between August 1999 and May 2001 Prime Minister Dzurinda had to dismiss four government members, which had been charged with corrupt behaviour. Among those accused were the ministers of economy, transport and defence. One of the corruption cases which attracted international attention was the resignation of the Slovak Deputy Prime Minister, Pavol Hamžík, in connection with irregularities in the distribution of European Union funds (Učen 2002: 1077). The second Dzurinda Government was also hit by several corruption affairs, leading to the resignation of three of its members (Malová and Učen 2007: 1105).

The Czech Republic and Slovakia do not only suffer from corruption among top-levels politicians. Studies point to the existence of a high level of corruption in different areas and at different levels of public administration (Anderson 2000; Lízal and Kočenda 2000). Public opinion polls reveal that in both societies corruption is perceived as one of the most important societal problems, requiring very urgent action (CVVM 2002; FOCUS 2004). Corruption is perceived to be widespread and especially problematic in the health services, justice, police and various government ministries (Anderson 2000; Lízal and Kočenda 2000; FOCUS 2004).

Of particular interest, and examined in this article, is the development of corruption in the Czech and Slovak Republics during their EU accession period. When taking a closer look at the developments in both countries we get a mixed picture. When we compare the level of corruption in the Czech Republic in 1998 with the level in 2004, little change can be noticed. The state of corruption at the time of accession on 1 May 2004 
had not improved compared to the period before the EU membership negotiations started. On the contrary, the Transparency International, World Bank and Freedom House indexes all show a small deterioration of the Czech corruption record across the years in question.

Table 1: Level of corruption in the Czech Republic in 1998 and 2004

\begin{tabular}{|c|c|c|c|}
\hline \multicolumn{2}{|c|}{ World Bank } & $\begin{array}{c}\text { Transparency } \\
\text { International }\end{array}$ & Freedom House \\
\hline $\mathbf{1 9 9 8}$ & & & \\
$(1999)^{3}$ & 67.50 & 4.80 & 3.25 \\
\hline $\mathbf{2 0 0 4}$ & 66.50 & 4.20 & 3.50 \\
\hline
\end{tabular}

In Slovakia the corruption record developed differently during its EU accession period. Starting off worse than the Czech Republic, Slovakia has achieved some success with its fight against corruption. The three corruption indices show that the level of corruption in the Slovak Republic was lower in 2004 compared to 1998. As a result the level of corruption in Slovakia in 2004 came close to that of the Czech Republic in the same year.

Table 2: Level of corruption in Slovakia in 1998 and 2004

\begin{tabular}{|c|c|c|c|}
\hline \multicolumn{2}{|c|}{ World Bank } & $\begin{array}{c}\text { Transparency } \\
\text { International }\end{array}$ & Freedom House \\
\hline $\mathbf{1 9 9 8}$ & & & 3.75 \\
$(1999)$ & 57.30 & 3.90 & 3.25 \\
\hline $\mathbf{2 0 0 4}$ & 69.40 & 4.00 & \\
\hline
\end{tabular}

According to this data, the perception of Czech corruption records during the period of the accession negotiations worsened, while the state of corruption in Slovakia on the other hand improved slightly. Faced with these developments one is tempted to take a closer look at how the fight against corruption has been handled by the EU during the accession process.

\section{European accession and the fight against corruption: applying the tools}

During the period of negotiations prior to the Eastern enlargement, the EU adopted several tools to exert influence on the domestic politics of the CEECs. By linking membership in the Union to the fulfilment of certain criteria the EU has tried to guide the candidate countries in terms of their democratic reforms. The basic (democratic) criteria drawn up at the Copenhagen European Council Summit in 1993 were to form the basis of the EU's Pre-Accession Strategy. The latter contained several elements which could provide the Union with a certain leverage on the domestic developments in the CEECs. The following section examines how the EU has made use of these tools to support the fight against corruption in the Czech Republic and Slovakia.

\section{Regular Reports}

The first element of the Pre-accession Strategy, used by the European Union to influence the domestic politics of the candidate countries, was the publication of a series of Regular Reports by the European Commission. These reports, drawn up annually from 1997, assessed the progress towards accession made by the different CEECs. They are unique in the Union's enlargement history, in the sense that they

${ }^{3}$ Freedom House assigns its first value on the level of corruption in the Czech Republic and Slovakia in 1999. No value is available for 1998. 
constituted the first active application of conditionality (Grabbe 2006a: 13). By monitoring the progress made by each of the candidate countries, the EU and specifically the Commission was able to differentiate between the various acceding countries and to influence internal developments through the ranking of the applicants (Grabbe 2006a: 83). The different reports were made public, which enacted an effective system of 'naming and shaming'.

In its Regular Reports the European Commission referred to the state of corruption in the Czech Republic and Slovakia. The Commission assessed the fight against corruption when reporting on compliance with the EU democratic criteria ${ }^{4}$. The references to corruption in the Czech Regular Reports bear great resemblance with those in the Slovak reports. At times identical wording is used to assess the situation in both countries.

In 1997 the Opinion Report on the Czech Republic and the Opinion Report on Slovakia both briefly mention the problem of corruption, related to the state of affairs in the civil service:

The public service is hindered somewhat by the absence of civil service regulations and the fact that salaries are relatively low, which explains why the most competent staff are leaving it for the private sector. All of these factors add to the difficulty in combating corruption (European Commission 1997a: 15).

The Slovak administration has no civil service code clearly defining the rights and obligations of civil servants. This makes it more difficult to combat the problems of corruption which the country is experiencing (European Commission 1997b: 16).

A second small reference can be found in the general evaluation of the political criteria, where both reports point out to the necessity of intensifying the fight against corruption.

Where the Opinion Reports mention corruption in two single lines, the subsequent Regular Reports on both countries provide a greater focus on the issue of anticorruption measures. In the 1997 Opinion Report reference to the fight against corruption constitutes less than two per cent of the description of the democratic situation in the Czech and Slovak Republic. In the subsequent years the attention for corruption grows, to reach a peak in the Czech Regular Report of 1999 and the Slovak reports of $2000 \& 2001$. The last reports on both countries dedicate almost 16 per cent of their description of democracy to the fight against corruption.

Table 3: Reference to 'Corruption' in the first chapter of the Opinion Reports (OR) and Regular Reports (RR). Number of words dedicated to the relevant subject.

\begin{tabular}{|l|l|l|l|l|l|l|}
\hline Czech Republic & OR 97 & RR 98 & RR 99 & RR 00 & RR 01 & RR 02 \\
\hline $\begin{array}{l}\text { Regular Report - } \\
\text { Political criteria } \\
\text { (No. of words) }\end{array}$ & 3417 & 1712 & 2712 & 5641 & 6350 & 8273 \\
\hline $\begin{array}{l}\text { Corruption } \\
\text { (referenced) }\end{array}$ & 64 & 177 & 509 & 770 & 706 & 1312 \\
\hline $\begin{array}{l}\text { Corruption } \\
\text { reference as \% of } \\
\text { first chapter }\end{array}$ & $1.87 \%$ & $10.34 \%$ & $18.77 \%$ & $13.65 \%$ & $11.12 \%$ & $15.86 \%$ \\
\hline
\end{tabular}

\footnotetext{
${ }^{4}$ In its Regular Reports the European Commission assesses the state of democracy in the candidate countries in the chapter on political criteria. This chapter is divided into two sections: 'democracy and the rule of law' and 'human rights and the protection of minorities'. The first part contains an assessment of the parliament, the executive, the judicial system and anti-corruption measures. The second part reflects on civil and political rights; economic, social and cultural rights; and minority rights and the protection of minorities.
} 


\begin{tabular}{|l|l|l|l|l|l|l|}
\hline Slovakia OR 97 & RR 98 & \multicolumn{1}{|l|}{ RR 99 } & \multicolumn{2}{|l|}{ RR 00 } & RR 01 & RR 02 \\
\hline $\begin{array}{l}\text { Regular Report - } \\
\text { Political criteria } \\
\text { (No. of words) }\end{array}$ & 3816 & 2659 & 3363 & 4408 & 5539 & 7751 \\
\hline $\begin{array}{l}\text { Corruption } \\
\text { (referenced) }\end{array}$ & 44 & 175 & 392 & 764 & 1022 & 1229 \\
\hline $\begin{array}{l}\text { Corruption } \\
\text { reference as \% of } \\
\text { first chapter }\end{array}$ & $1.15 \%$ & $6.58 \%$ & $11.66 \%$ & $17.33 \%$ & $18.45 \%$ & $15.86 \%$ \\
\hline
\end{tabular}

In general the Regular Reports describe which steps have been taken by the national government in fighting corruption. Subsequently they identify the main obstacles which hamper an effective anti-corruption policy, i.e. inadequate staff; a lack of specialised training and equipment financing; low pay for state employees; a lack of effective cooperation among the law enforcement institutions involved; insufficient legislation; the duplication of work between the police and investigators, and the insufficient police powers to investigate offences. The Regular Reports also mention the state of affairs in terms of the ratification of several international conventions related to laundering, bribery and corruption (i.e. 'Council of Europe Convention on Money laundering, Search, Seizure and Confiscation of the Proceeds from Crime and on the Financing of Terrorism'; 'Council of Europe Criminal Law Convention on Corruption'; 'OECD Convention of Combating Bribery of Foreign Public Officials in International Business Transactions'; 'Council of Europe Civil Law Convention on Corruption').

In the course of the successive reports different topics are discussed when the Commission assesses the anti-corruption measures. Besides corruption and bribery, reference is made to the problem of money-laundering, fraud, economic crime, institutional theft and asset-stripping. More detailed problems referred to in the reports relate to public procurement; the lack of a Civil Service Law; the weakness of several legislative measures (e.g. the Act on Conflicts of Interest and the Code of Civil Service Ethics); the vagueness of the National Programme for the Fight against Corruption and problems related to party financing and the functioning of the different institutions involved in the fight against corruption. Additionally the reports briefly touch upon the perceptions of the public on corruption within the different spheres of daily life.

Reference to corruption can also be found in the Commission's assessment of the judiciary in the Czech and Slovak Republics. In general the EU denounces the lack of specialised training of the judges, and refers to the need for modern equipment and information technology, as well as the fact that the judiciary is chronically understaffed and, as a result, overloaded. Related to the fight against corruption, the Commission identifies the fact that the judiciary faces problems with regard to its independence and political neutrality, its weak performance in the fight against economic crime, and the lack of specialisation of judges and state prosecutors in the areas of economic crime, corruption and money laundering. Reference is often made to the existence of a high level of corruption in the judiciary.

The fight against corruption is also mentioned in the third part of the Regular Reports. This part assesses the progress of the candidate countries' compliance with the acquis communautaire. The chapters on free movement of services, free movement of capital, justice and home affairs and financial questions all report on the necessity of increased action in the domains of combating money laundering, fraud and corruption. The chapter on free movement of services and the chapter on free movement of capital assess inter alia the state of affairs of the financial services supervision and the progress made in fighting fraud and money laundering. They also assess compliance with the EU Money Laundering Directive. The chapter on justice and home affairs often repeats the necessity to undertake measures concerning the independence of the judiciary and the 
problems of accountability of the police as an important priority in the development of effective institutions free of corruption. The chapter on financial questions reports on external and internal financial control and audit functions of the candidate countries. Overall, the different chapters assess the progress made in legislative alignment and identify the gaps which remain in adoption of the acquis.

Reference to corruption in the third part of the Regular Reports is considerably smaller than the attention paid to the subject in the parts which assess the democratic progress of both countries. The amount of attention paid to fighting corruption when assessing compliance with the acquis stays relatively stable and varies between 2.37 and 5.70 percent.

Table 4: Reference to corruption in the third chapter of the Opinion Reports (OR) and Regular Reports (RR). Number of words dedicated to the relevant subject.

\begin{tabular}{|l|l|l|l|l|l|l|}
\hline Czech Republic OR 97 & RR 98 & RR 99 & RR 00 & RR 01 & RR 02 \\
\hline $\begin{array}{l}\text { Regular Report - Ability } \\
\text { to assume the obligations } \\
\text { of membership (No. of } \\
\text { words) }\end{array}$ & 26666 & 5553 & 12780 & 29968 & 32293 & 41299 \\
\hline Corruption (referenced) & 878 & 298 & 728 & 1448 & 1297 & 1687 \\
\hline $\begin{array}{l}\text { Corruption reference as } \\
\% \text { of third chapter }\end{array}$ & $3.29 \%$ & $5.37 \%$ & $5.70 \%$ & $4.83 \%$ & $4.02 \%$ & $4.08 \%$ \\
$\begin{array}{l}\text { Slovakia } \\
\begin{array}{l}\text { Regular Report - Ability } \\
\text { to assume the obligations } \\
\text { of membership (No. of } \\
\text { words) }\end{array}\end{array}$ & 27083 & 6034 & 11227 & 22923 & 27419 & 38759 \\
\hline Corruption(referenced) & 641 & 270 & 588 & 1.063 & 1.151 & 1.571 \\
\hline $\begin{array}{l}\text { Corruption reference as } \\
\% \text { of third chapter }\end{array}$ & $2.37 \%$ & $4.47 \%$ & $5.24 \%$ & $4.64 \%$ & $4.20 \%$ & $4.05 \%$ \\
\hline
\end{tabular}

The section on corruption in the final Regular Report (2002) starts with the conclusion that corruption remains a serious cause for concern in the Czech Republic (European Commission 2002a: 24), as well as in Slovakia (European Commission 2002b: 25). In all the Regular Reports produced for the two countries, the evaluation of the anticorruption measures, as well as the evaluation of the judiciary, cautiously praise the steps taken by both countries, but also make reference to the fact that severe problems remain to be tackled. From the considerate amount of attention paid to corruption in the 2002 reports, it is possible to conclude that the European Commission was well aware that corruption remained a serious problem in both countries. Nevertheless, at the December 2002 European Council Summit in Copenhagen, both countries closed their negotiations to join the Union and were given an accession date of 1 May 2004. In the end it seems that the fight against corruption was not considered decisive enough to halt the political dynamic of the accession process.

\section{Short and Medium-term Priorities and Objectives}

A second instrument applied by the EU as a trigger for reform in the CEECs was the Short and Medium-term Priorities and Objectives. These were part of the Accession Partnerships, which were drawn up separately for each applicant state, to provide guidance and encouragement during the membership preparations. The Short and Medium-term Priorities and Objectives were decisions from the Council of the EU, highlighting the priority areas which it deemed as requiring to be addressed by the candidate countries in order to prepare for accession. They determined, on a country- 
by-country basis, the particular needs on which pre-accession assistance would be targeted. The documents stated explicitly the achievement of the objectives as conditioning the degree of financial assistance granted. A separate clause on conditionality even mentioned that failed progress in implementing the accession partnership could lead to a decision by the Council to suspend financial assistance. For example, the Czech agreement noted:

\begin{abstract}
Community assistance will be conditional on respect by the Czech Republic of its commitments under the Europe Agreement, further steps towards satisfying the Copenhagen criteria and progress in implementing this accession partnership. Failure to respect these general conditions could lead to a decision by the Council on the suspicion of financial assistance on the basis of Article 4 of Regulation (EC) No 622/98. (Council of the European Union 1998: paragraph 5)
\end{abstract}

The Short and Medium-term Priorities and Objectives were expected to influence the dynamics of the negotiating process with the different CEECs.

Short and Medium-term Priorities and Objectives were drawn up for the Czech and Slovak Republics in 1998, 1999 and 2002. For both countries corruption was identified in each of the Council decisions as an area of urgent attention. Additionally, several corruption-related issues, in line with those identified in the Regular Reports (public procurement, bankruptcy laws, independence of the judiciary, financial control, money laundering, etc.) were marked as priority areas which required immediate action by the candidate countries.

Table 5: Direct reference to the fight against corruption in the Short and Medium-term Priorities and Objectives

\begin{tabular}{|c|l|}
\hline 1998 & $\begin{array}{l}\text { Czech Republic } \\
\text { and corruption }\end{array}$ \\
\hline 1999 & $\begin{array}{l}\text { - Implement policy on organised crime, corruption and economic crime; } \\
\text { ratify the OECD convention on bribery; sign the European criminal law } \\
\text { convention on corruption } \\
\text { - Continue the fight against organised crime and corruption }\end{array}$ \\
\hline $\mathbf{2 0 0 2}$ & $\begin{array}{l}\text { - Pursue efforts to more effectively fight against corruption and } \\
\text { economic crime }\end{array}$ \\
$\begin{array}{l}\text { - Establish a framework for cooperation between different law } \\
\text { enforcement agencies, especially concerning the fight against financial } \\
\text { crime and corruption }\end{array}$ \\
\hline
\end{tabular}

\begin{tabular}{|l|l|}
\hline 1998 & - Fight organised crime and corruption \\
\hline $\mathbf{1 9 9 9}$ & $\begin{array}{l}\text { - Ratify the European Convention on money laundering, the European } \\
\text { criminal law convention on corruption and the OECD Convention on } \\
\text { bribery } \\
\text { - Continue the fight against organised crime and corruption }\end{array}$ \\
\hline $\mathbf{2 0 0 2}$ & $\begin{array}{l}\text { - Step up the fight against corruption and economic crime, in particular } \\
\text { ensure the timely and effective implementation of the action plan to } \\
\text { combat corruption }\end{array}$ \\
\hline
\end{tabular}

Based on the extensive reference to fighting corruption, we can conclude that the European Union has made optimal use of the instrument of the Short and Mediumterm Priorities and Objectives to support the fight against corruption in the Czech Republic and Slovakia. 


\section{Financial aid}

A third instrument used by the EU to support the CEECs in their transformation to liberal democracy was financial and technical assistance. In 1989 the OECD set up a major project of financial aid, known as PHARE (Pologne, Hongrie: aide à la Reconstruction Économique). The coordination of the PHARE programme was assigned to the European Commission. The levels of financial aid allocated through the PHARE programme meant that it had great potential for influencing the CEECs (Smith 2004: 70)..$^{5}$

The financial assistance provided by PHARE created the stimulus for the massive reforms which had to be carried out, but it was actively linked to the fulfilment of certain democratic criteria (Smith 2004: 70-71). To be eligible for financial support, five political conditions had to be met: commitment to the rule of law, respect for human rights, the establishment of multi-party systems, the holding of free elections, and the implementation of economic liberalisation. This conditionality formed the basis on which financial support was provided - at least on paper. The democratic criteria linked to the PHARE Programme were primarily deemed as the criteria of formal democracy. However, fulfilling the Short- and Medium-term Priorities and Objectives was also a prerequisite for receiving financial help. Since these documents mention corruption as a priority area for both countries, fighting corruption became de facto a condition for financial assistance.

The PHARE funds were distributed through several programmes, depending on the beneficiary countries involved. Most important were the National Programmes, which were separately developed for each candidate country on an annual basis. They focused on a limited number of key priorities, identified on the basis of the Regular Reports, the Short- and Medium-term Priorities and Objectives and the provisions of the National Programme for the Adoption of the Acquis.

An examination of the PHARE projects teaches us that in the framework of the Czech National Programmes, the Commission dedicated two projects - worth $€ 4.10$ million solely to the fight against corruption. ${ }^{6}$ The existence of only two dedicated corruption projects in the time span of nine years ${ }^{7}$ might seem negligible as financial support. A number of PHARE projects, however, were linked to corruption by specifically including the fight against corruption as one of their main, though not sole, objectives. The European Union assigned $€ 12.30$ million to ten of these projects. In the end several projects were allocated money to deal with problems which had been identified in the Regular Reports as relevant for the fight against corruption. These projects did not mention the fight against corruption as a direct aim but they provide financial help to domains where improvement can only be beneficial with regard to the problem of corruption These projects addressed issues such as the strengthening of the judiciary and law enforcement, the fight against organised crime and money laundering, the strengthening of the institutional and administrative capacity, and so on. The European Commission referred to these issues when assessing corruption in its Regular Reports.

\footnotetext{
${ }^{5}$ PHARE is only one of the three pre-accession financial instruments which the Commission developed to support the membership preparation of the candidate countries. In 1999 two additional financial instruments were created: ISPA and SAPARD. ISPA (Instrument for Structural Policies for PreAccession) focused on the improvement of the environmental and transport infrastructure, while SAPARD (Special Accession Programme for Agriculture \& Rural Development) supported the agricultural and rural development in the candidate countries. Both structural instruments took effect from 2000, and as a result of which, PHARE no longer financed projects in these areas.

${ }^{6}$ There are a wide range of relevant PHARE programmes, examples of which include CZ 01-07-06: "Improving the fight against corruption and economic crime" and CZ 2005/017/518.04.02: "Reinforcement of the Czech police capacity in combating corruption and economic crime".

${ }^{7}$ In the years of EU accession negotiations, PHARE projects have been drawn up from 1998 to 2006. From 2004 on they are part of the Transition Facility.
} 
From a financial perspective the various National Programmes for the Czech Republic provided a sum total of $€ 36.14$ million to 24 such projects.

In a parallel way the European Union has also provided financial help to the Slovak Republic to support its fight against corruption. Four projects, for an amount of $€ 7.78$ million, have been dedicated directly and solely to the fight against corruption. Seven corruption-related projects have provided Bratislava with $€ 11.45$ million of financial aid. Finally the European Union assigned $€ 29.30$ million to 19 projects addressing problems related to the fight against corruption.

Table 6: PHARE financial aid dedicated to the Czech Republic to support the fight against corruption

\begin{tabular}{|l|l|l|}
\hline Czech Republic & $\begin{array}{l}\text { Money } \\
\text { allocated } \\
\text { /€ million }\end{array}$ & $\begin{array}{l}\text { Per cent of total } \\
\text { amount of money } \\
\text { allocated }\end{array}$ \\
\hline $\begin{array}{l}\text { Total amount of money allocated under the } \\
\text { PHARE National Programmes to the Czech } \\
\text { Republic (1998-2006) }\end{array}$ & 380 & $100 \%$ \\
\hline $\begin{array}{l}\text { Amount of money allocated solely to the } \\
\text { fight against corruption }\end{array}$ & 4.10 & $1.08 \%$ \\
\hline $\begin{array}{l}\text { Amount of money allocated to corruption- } \\
\text { linked projects }\end{array}$ & 12.30 & $3.27 \%$ \\
\hline $\begin{array}{l}\text { Amount of money allocated to corruption- } \\
\text { relevant projects }\end{array}$ & 36.14 & $9.54 \%$ \\
\hline $\begin{array}{l}\text { Total amount of money allocated under the } \\
\text { Czech National Programmes to support the } \\
\text { fight against corruption }\end{array}$ & 52.54 & $13.87 \%$ \\
\hline
\end{tabular}

Table 7: PHARE financial aid dedicated to Slovakia to support the fight against corruption

\begin{tabular}{|l|l|l|}
\hline Slovakia & $\begin{array}{l}\text { Money } \\
\text { allocated / } \\
€ \text { million }\end{array}$ & $\begin{array}{l}\text { Per cent of total } \\
\text { amount of money } \\
\text { allocated }\end{array}$ \\
\hline $\begin{array}{l}\text { Total amount of money allocated under } \\
\text { the PHARE National Programmes to } \\
\text { Slovakia (1998-2006) }\end{array}$ & 330 & $100 \%$ \\
\hline $\begin{array}{l}\text { Amount of money allocated solely to the } \\
\text { fight against corruption }\end{array}$ & 7.78 & $2.36 \%$ \\
\hline $\begin{array}{l}\text { Amount of money allocated to corruption- } \\
\text { linked projects }\end{array}$ & 11.45 & $3.47 \%$ \\
\hline $\begin{array}{l}\text { Amount of money allocated to corruption- } \\
\text { relevant projects }\end{array}$ & 29.30 & $8.88 \%$ \\
\hline $\begin{array}{l}\text { Total amount of money allocated under } \\
\text { the Slovak National Programmes to } \\
\text { support the fight against corruption }\end{array}$ & 48.53 & $14.72 \%$ \\
\hline
\end{tabular}

The EU has provided a considerable amount of money to the Czech and Slovak Republics - albeit indirectly - to support the fight against corruption. Most of this money was dedicated to projects which had an impact on the reduction of corruption, but which were not specifically designed to tackle the route source of the corruption. This makes it harder to assess the impact of these projects on the overall problem of corruption. Those projects dedicated solely to fighting corruption provided the candidate countries with a much smaller amount of money. This is striking when we 
take into account the attention paid to corruption in the Regular Reports, where the Commission proved to be well aware of the magnitude of the problem.

\section{Explaining the limited impact of EU aid to fighting corruption}

As has been shown above, the European Union applied a number of political and economic tools during the accession process to support the Czech Republic and Slovakia in their fight against corruption. Despite many political and financial incentives, perceived levels of corruption in both countries failed to improve radically by the time both countries joined the European Union. This section examines why the methods used by the EU to help combat corruption did not seem to trigger any major immediate results. Firstly, there is a focus on the European level and acknowledgement of those aspects of the EU's enlargement policy which tempered the scope of influence on the candidate countries. Secondly, there is a focus on the domestic level of the two case study states and an examination of the power of national policies in determining the impact of the EU on matters of democratisation.

\section{Restrictions inherent to EU policies}

\section{Enforcing change: acquis transposition}

Throughout the Eastern enlargement process the EU has linked membership in the Union to the fulfilment of certain criteria. These conditions had to be met before the EU would agree to open accession negotiations with an applicant country. In the first phase of EU accession, issues concerning democratic consolidation were given an important place in the political relations between the EU and the CEECs. The democratic reforms of the candidate countries were regularly scrutinised by the European Commission, and the European Council would decide to open accession negotiations, only when a certain level of democracy was achieved. Once the negotiations started however, there was a shift in the political focus of enlargement conditionality. During the period of EU accession negotiations the European Commission and the governments of the various candidate states focused mainly on the transposition of the acquis communautaire, and less on issues of democracy. Administrative and bureaucratic considerations prevailed over issues of democratisation (De Ridder et al. 2008: 250; Pridham 2002: 958). Schimmelfennig and Sedelmeier (2004: 669-671) refer to this shift as the change from democratic conditionality to acquis conditionality.

When assessing the effectiveness of EU conditionality on corruption, it is necessary to make a distinction between the EU's political requirement of fighting corruption (democratic conditionality), and the Union's anti-corruption demands as part of the third Copenhagen criterion (acquis conditionality). The latter implied the 'downloading' of the acquis communautaire, with little or no scope for real negotiations or opt-outs. Legal transposition of the acquis was essential to enter the Union and soon became the central focus of the accession process. The fact that the criteria of implementing the acquis contained concrete and tangible laws and demands increased the leverage of the EU to bring about change in the CEECs.

Transposition of the acquis was the main focus of the accession negotiations between the CEECs and the European Commission. The EU's anti-corruption instruments are laid down in the acquis on organised crime, fraud and corruption, which is part of the Community laws on Justice and Home Affairs. Besides the obligation of acceding to two EU conventions on corruption (the EU Convention on the Protection of the European Communities' Financial Interests (Official Journal C 316, 27.11.1995) and the EU Convention on the Fight against Corruption involving Officials of the European Communities or Officials of the EU Member States (Official Journal C 195, 25.06.1997), 
the member states - and thus candidate countries - are also obliged to accede to several international anti-corruption conventions. The acquis also puts forward three conventions on corruption, to which accession is desirable, though not compulsory. These are: (1) The OECD-Convention on Combating Bribery of Foreign Public Officials in International Business Transactions, (2) the Council of Europe Criminal Law Convention on Corruption and (3) the Council of Europe Civil Law Convention on Corruption. Taking into regard the limited legal framework on corruption, there was little real development on the issue of corruption during the accession negotiations. Reference to the subject of corruption was confined to a brief mention of the state of affairs in the introductory remarks to a negotiation session (interview Petr Kubernát 28 May 2008; interview Jiří Havlik 4 June 2008).

In the context of the third Copenhagen criterion, the EU was able to claim some successes, such as alignment of the candidate countries with the anti-money laundering legislation of the Union and their ratification of key international conventions on corruption and bribery. In this context, the European Commission made use of the instrument of benchmarking in its reports to trigger change in the candidate countries. The Czech Republic and Slovakia were criticised in their respective 1999 Regular Reports, for not having ratified the OECD Convention on Combating Bribery and the Council of Europe Criminal Law Convention on Corruption (European Commission 1999a: 14; 1999b: 15). Shortly after these negative assessments both conventions were ratified and entered into force in both republics.

By setting the transposition of the acquis as an obligation for membership, the Union acquired some political leverage within the acceding countries. Nevertheless, the power of this 'tool' of influence proved to have its limits. For example, although the acquis obliged the candidate states to become signatories to various international conventions, the Union has not been able to force the Czech Republic to ratify the UN Convention Against Transnational Organized Crime. While transposition of the entire acquis - and thus ratification of the convention - was a prerequisite for entering the Union, which the Czech Republic did not meet, the EU nonetheless granted it membership. Worth mentioning in this context is the fact that the EU required accession by the candidate countries to international conventions, which had not been ratified by several of the incumbent member states. ${ }^{8}$ This inconsistency effectively decreased the potential leverage of the EU to make hard demands towards the candidate countries.

\section{Vagueness of EU democratic policies}

The obligation to implement the rules and laws of the acquis communautaire provided the EU with some, albeit limited, scope of influence. However, in domains which lay outside EU regulatory policy, the influence of the Union has been less clear, particularly during the accession process (Grabbe 2006a: 24). This was often the case for issues of substantive democracy, such as media independence, judicial reform, promotion of civil society, local government, and many more. In the context of these policy areas the EU frequently called for 'major efforts' to improve or strengthen policies and institutions, without specifying the means to reach this objective (Grabbe 2006a: 24). This was evident when the Commission evaluated the anti-corruption measures in the Czech and Slovak Regular Reports. Although extensive attention was paid to the fight against corruption, the largest part of the Regular Report evaluations contained a descriptive overview of the anti-corruption steps taken by the national government. The Commission pointed out that, in spite of some efforts undertaken, these did not

\footnotetext{
${ }^{8}$ Ten incumbent EU member states had failed to ratify the UN Convention Against Transnational Organzed Crime by the accession date of 1 May 2004. Two of these states, Greece and Ireland, have still to ratify this convention. For full details of signatories see: http://www.unodc.org/unodc/en/treaties/CTOC/countrylist.html, last accessed 26 October 2008.
} 
provide a sufficient solution to the problem, since no major improvement could be found. Rarely did the Commission take the issue a step further and detail what exactly could be done or had to be done to tackle these problems. If the reports did touch upon future requirements, these remained mainly abstract in terms of 'stepping up efforts', 'improving law enforcement' and 'filling legislative gaps'. These recommendations were issued ad hoc, without a structural and well-defined approach towards necessary anti-corruption measures. In the end it was not clear what was expected to be done in the future by the domestic governments in order to comply with EU anti-corruption demands.

On several occasions the European Parliament denounced the fact that the EU lacked clear solutions to present to the CEECs for many of the conditionality concerns the EU held. As early as 1997, various MEPs called on the European Commission to draw up comprehensible and verifiable criteria for the process of democratisation in Central and Eastern Europe, and to put in place policies and instruments which effectively tackled identified problems, such as that of corruption (European Parliament 1997). Regardless of these requests the European Commission never elaborated clear and unambiguous anti-corruption criteria to be fulfilled by the candidate countries. This vagueness on the part of the Commission has to be linked to the fact that the European Union never reached any conceptual clarity on what constitutes a consolidated democracy. Instead the EU conditions on democracy have been pragmatically handled and incrementally developed without involving any comprehensive review or understanding of liberal democracy (Pridham 2006: 381).

The EU has been very slow in developing a definition of its political criteria because it did not possess institutional templates for any of these conditions. The European Union set the political criteria for the candidates, but these criteria largely remain outside EUlevel responsibilities (Grabbe 2001; Olsen 2002; Bulmer and Radaelli 2005). Along the same line of reasoning we can link the vagueness of the Union's anti-corruption policy during the Eastern enlargement process to the fact that the EU did not possess a clear and enforceable anti-corruption framework of its own. Although various EU institutions have called for a comprehensive approach towards fighting corruption inside the Union (e.g. Vienna Action Plan 1998; Tampere European Council 1999; Millennium Strategy on the Prevention and Control of Organised Crime 2000), the EU has developed very little in the way of effective legal instruments in this domain. As already mentioned, the EU did establish two relevant conventions: the EU Convention on the Protection of the European Communities' Financial Interests (Official Journal C 316, 27.11.1995) and the EU Convention on the Fight against Corruption involving Officials of the European Communities or Officials of the EU Member States (Official Journal C $195,25.06 .1997)$. The main focus of both conventions however, is the protection of the financial interests of the European Communities. The same is true for the European Anti-Fraud Office (OLAF), which was created in 1999, with the aim of combating fraud and other illegal activities, detrimental to the Community's interests. As far as tackling corruption at the national level of the member states, the legal framework elaborated by the European Union is limited. Legal instruments such as the EU money-laundering directives and public procurement directives contain some provisions which are relevant for fighting corruption at a national level, but the EU has never established clear common rules or minimum standards for fighting corruption within its member states. The domain of corruption and fighting corruption remains largely in the realm of national power, which reduces the scope of the EU to make strong demands towards the applicant countries. This despite the fact that problems at a national level can have a supranational dimension due to the fact that the EU is the sum of its constituent (national) parts. The absence of EU-wide standards for fighting corruption severely curbed the space for the EU, during the accession process, to draw up strong criteria for its future member states. 


\section{The power of national politics}

When we assess the influence of the European Union on tackling corruption - or on democratic issues more generally - there is a meaningful domestic factor which has to be taken into account. Several authors (Schimmelfennig and Sedelmeier 2004 and 2005a; Vachudová 2001) point to the importance of Central and Eastern European domestic actors, which determine the level of compliance with EU demands. Schimmelfennig and Sedelmeier (2005a: 16-17) claim that domestic change as a result of complying with conditionality criteria set by an external actor is a costly operation for a target government. A weighing up of the different costs experienced by the different domestic veto players, whose agreement is necessary to bring about domestic change, determines the compliance level with the required criterion.

However, as seen above, the EU presented the CEECs with very little specific anticorruption criteria to comply with. During the entire accession process the Union remained vague about what exactly had to be done by a candidate country in order to meet its anti-corruption demands. In its Regular Reports the European Commission called upon the candidate countries to improve their fight against corruption. But since no clear standards or benchmarks were offered by the EU, the candidate countries remained largely free to decide for themselves about how best to tackle the problem of corruption. Both the Czech Republic and Slovakia have developed several measures to fight corruption, such as launching national programmes on fighting corruption, adopting resolutions with the same aim, amending the criminal code and establishing specialised units responsible for anti-money laundering and anti-corruption policy. However, the impact of these measures has differed widely.

The European Commission took account of the national efforts to combat corruption in its Regular Reports. It concluded that for the Czech Republic and for Slovakia, insufficient manpower, equipment, financing, a lack of transparency and coordination between the different agencies involved and the existence of low pay for employees constituted serious obstacles to an effective anti-corruption approach. At the same time the European Commission pointed out the importance of national politics. In the 2001 Czech Regular Report the European Commission stressed the role of domestic political actors when stating "there continues to be a need for clear political leadership and setting of example from all political figures in order to create a more favourable environment for [...] anti-corruption measures" (European Commission 2001: 21). Due, on the part of the EU, to the lack of clear anti-corruption criteria and the goals to be reached, the anti-corruption agenda during the years of EU accession was mainly pushed by national level undertakings of the CEECs.

The salience of corruption and, to a lesser degree, the will to tackle corruption in the Czech Republic and Slovakia is reflected in the government programmes of both countries. These programmes were submitted to the respective national parliament in order to receive an approval. The programmes contain references to the fight against corruption. Relevant for our period of research are the programmes of the Tošovský, Zeman and Špidla governments in the Czech Republic. After the fall of the Klaus government at the end of 1997, the Czech Republic was lead by a caretaker government for seven months, headed by Josef Tošovský. A new government took office in July 1998 with the appointment of Miloš Zeman as Prime Minister. He was succeeded in July 2002 by Vladimír Špidla, who headed the government until after the country's EU accession. In their programmes, all three Czech governments promised to tackle the problem of corruption in the country. For example, the programme of the Zeman government included a reference to address corruption with regard to the privatization process and within public administration. In addition, the government proposed to increase the transparency of the capital market, economic policies and public finances. The succeeding Špidla government laid stress on fighting corruption in the justice sector, the police force and the civil service. No references were made to increasing transparency in specific policy areas. When we compare both governments, 
fighting corruption proved to be more salient for the Zeman Government than for the government lead by Vladimír Špidla (see table 8).

As regards Slovakia, Prime Minister Mikuláš Dzurinda headed two successive governments during the EU accession negotiations. The programmes of both governments included the issue of fighting corruption in Slovakia. The first Dzurinda Government (1998 - 2002) promised to tackle the occurrence of corruption in various sectors, such as public administration, economy, justice, and education. The cabinet declared the fight against economic crime a priority during its four years of office. In the programme of the second Dzurinda Government $(2002-2006)$ we can see a radical increase in the attention paid to the issue of corruption. Fighting corruption became a common theme throughout the whole government declaration, reoccurring in no less than 12 policy domains. The government programme added several areas in which it would fight corruption: for example, the social and health-care sector, internal security and the armed forces. This particular government programme also provided details of methods when referring to the fight against corruption (e.g. the granting of licences in the transport, post and telecommunications sector, or the allocation of agricultural subsidies, and the development of an open public procurement system). In addition the government committed itself to increasing the transparency of 14 policy sectors. Almost $6 \%$ of the entire government programme was dedicated to the issue of fighting corruption (See Table 8).

The government programmes show that from the end of the 1990s fighting corruption appeared on the political agenda in the Czech Republic and Slovakia. A difference between both countries however, can be noticed with regard to the salience of the topic. While references to corruption decreased in the Czech Republic, the attention for corruption issues in Slovakia grew considerably. This was particularly so under the second Dzurinda Government, when fighting corruption proved to be a priority in Slovakia in the immediate run up to its accession to the EU. This difference might explain the diverging development of the Czech and Slovak corruption records between 1998 and 2004.

Table 8: Reference to corruption in the Czech and Slovak government programmes

\begin{tabular}{|c|c|c|c|}
\hline & Government & Period of office & $\begin{array}{l}\text { Reference } \\
\text { to } \\
\text { corruption* }\end{array}$ \\
\hline \multirow{3}{*}{$\begin{array}{l}\text { CZECH } \\
\text { REPUBLIC }\end{array}$} & Tošovský government & $01 / 1998-07 / 1998$ & $1.38 \%$ \\
\hline & Zeman government & $07 / 1998-07 / 2002$ & $1.69 \%$ \\
\hline & Špidla government & $07 / 2002-08 / 2004$ & $0.99 \%$ \\
\hline \multirow[t]{2}{*}{ SLOVAKIA } & Dzurinda government I & $10 / 1998-10 / 2002$ & $1.22 \%$ \\
\hline & Dzurinda government II & $10 / 2002-07 / 2006$ & $5.72 \%$ \\
\hline
\end{tabular}

* number of words which refer directly to corruption (as percentage of the total number of words of the government programme)

It is possible to conclude that developments in the area of deeper or substantive democracy in the years of EU accession were mainly guided by national incentives, and less by EU enlargement policies. In case a national government did not adhere to reform in a certain domain of substantive democracy - because it was considered too costly in terms of political power - there were very few means that the EU could employ to circumvent the individual country's reluctant stance towards reform. As Heather Grabbe (2006b: 3) points out, "the Commission provides accession countries with financial and technical assistance, but while the EU can provide the tools and political incentives to bring about change, these are of no use unless they are taken up by national leaders". 


\section{A glance at the future}

Together with six other CEECs, the Czech Republic and Slovakia joined the European Union on 1 May 2004. As a result the European Union could no longer apply its preaccession tools linked to conditionality, which had the potential of influencing the Central and Eastern European candidate countries. However, as shown above, the application of the pre-accession instruments appeared to bring little significant change to the corruption records of the Czech Republic and Slovakia during the accession process. This is likely to become even more relevant following accession because the EU has lost an opportune chance to stimulate changes in the corruption records of its new members. As fully-fledged members of the EU the CEECs are no longer subject to (democratic) conditionality as applied during the accession process. Compliance with the acquis communautaire remains compulsory, but as seen above the EU legal framework on corruption is limited.

The European Union now faces the reality that following enlargement it has 'adopted' a number of states with higher levels of corruption than many (though not all) of its incumbent members. This was further emphasised following the 2007 enlargement towards Romania and Bulgaria. Faced with the persistent high levels of corruption in these two states at the time of their EU accession, the Union tried to protect its own interests by establishing a safeguard clause applicable to issues of justice and home affairs. The clause implied, amongst others, a continued monitoring of the state of corruption in both countries. Recent Commission reports on the state of corruption in Bulgaria, and to a lesser degree in Romania, however, raise doubts about the impact of this provision (European Commission 2008a, 2008b, 2009a and 2009b).

The accession of the CEECs has not been the endpoint of the EU enlargement policy. Today three countries have been granted the status of candidate country, while several more are aspiring membership. The latter are mainly countries from the Balkans region, an area which continues to be challenged by higher than average levels of corruption. If the European Union is committed to bringing about changes in the corruption records of these countries, it will have to make changes to its own anti-corruption policy applied during (and possible after) the enlargement process. If the EU does not elaborate clear anti-corruption criteria or elaborate on its legal framework for fighting corruption, no major influence on the corruption records of its (potential) candidate countries can be expected.

\section{Conclusion}

During the Eastern enlargement process the European Union decided to support the CEECs in their transformation towards liberal democracy. The EU made use of several means to trigger domestic change in CEE and to guide the countries through their democratising reforms. The extent of leverage that the Union had on the democratisation of CEECs is questionable. For example, the European Union has been able to influence the formal level of democracy by establishing a criteria of formal democracy as a prerequisite for accession and financial aid. However, when looking at democratisation from a substantive level, the leverage of the Union proved to be much more limited.

This has been evident when examining the influence of the European Union on the fight against corruption in the Czech Republic and Slovakia. The Union applied the means at its disposition to bring about positive change. It has handled the problem of corruption through (1) providing extensive comments within its Regular Reports (shaming), (2) promoting the Accession Partnerships and (3) through the provision of financial help. However, these incentives were not strong enough to substantially improve the corruption record of both countries by the time they joined the EU in 2004. 
The lack of success in triggering an effective anti-corruption policy in these countries can be linked to the limited institutional power of the European Union in the domain of substantive democracy. The Union was not able (or willing?) to make strong demands on the fight against corruption because there exists no competence for this policy inside the Union itself. As a result the different demands towards the accession countries remained vague and were issued in an ad hoc manner. The fact that the EU did not provide a clear-cut anti-corruption policy for the acceding countries to adopt, severely limited its scope to influence the candidate countries in terms of the fight against corruption. As a result, changes in the corruption records during the EU accession process heavily relied on national incentives. Due to the vagueness of direction coming from the European Union, the fight against corruption in the candidate countries was mainly determined by policies on the national level.

We can conclude therefore, that although the EU has applied several means at its disposal to influence the fight against corruption within its Central and East European states during their accession process, they did not prove to be powerful enough to trigger major changes. This means that in the end the scope for the EU to influence substantive democracy remains very limited when the efforts of the Union are not backed up by willing national actors.

\section{References}

Allnutt, L., J. Druker and J. Tracy (2001). 'Central Europe, Southeast Europe and the Baltic States', in R. Hodess (ed), Global Corruption Report. Berlin: Transparency International, pp. 124-137.

Anderson, J. (2000). Corruption in Slovakia: results of diagnostic surveys. Prepared the request of the Government of the Slovak Republic by the World Bank and the United States Agency for International Development. Available at: http://www.worldbank.org/wbi/governance/pdf/guide pdfs/slovrep44.pdf, last accessed 6 April 2009.

Appel, H. (2001). 'Corruption and the collapse of the Czech transition miracle', East European Politics and Societies, 15, pp. 528-553.

Brokl, L. and Z. Mansfeldová (2000). 'Czech Republic', European Journal of Political Research, 38 (3-4), pp. 354-365.

Bulmer, S. and C. Lequesne (eds) (2005). The Member States of the European Union. Oxford: Oxford University Press.

Bulmer, S. and C. Radaelli (2005). 'The Europeanisation of National Policy?', in S. Bulmer and C. Lequesne (eds), The Member States of the European Union. Oxford: Oxford University Press.

Council of the European Union (1998). Council Decision of 30 March 1998 on the principles, priorities, intermediate objectives and conditions contained in the accession partnership with the Czech Republic. (98/267/EC), Official Journal L 121, 23.04.1998, pp. $0041-0045$.

CVVM (2002), 'Jaké Problémy Občany Znepokojuji', ('Which Issues is the Public Concerned About?) Press release 28 May 2002. Available at: http://www.cvvm.cas.cz/index.php?disp=zpravy\&lang=0\&r=1\&s=\&offset=\&sh=1 00068, last accessed 6 April 2009.

De Ridder, E., A. Schrijvers and H. Vos (2008). 'Civil Power Europe and the Eastern Enlargement', in J. Orbie (ed), Europe's Global Role: External Policies of the European Union. Aldershot: Ashgate, pp. 239-257. 
European Commission (1997a). Agenda 2000 - Commission Opinion on the Czech Republic's Application for Membership. Doc /97/17.

European Commission (1997b). Agenda 2000 - Commission Opinion on Slovakia's Application for Membership. Doc /97/20.

European Commission (1999a). 1999 Regular Report from the Commission on Czech Republic's Progress towards Accession.

European Commission (1999b). 1999 Regular Report from the Commission on Slovakia's Progress towards Accession.

European Commission (2001). 2001 Regular Report on Czech Republic's Progress towards Accession. SEC(2001) 1746.

European Commission (2002a). 2002 Regular Report on Czech Republic's Progress towards Accession. SEC(2002) 1402.

European Commission (2002b). 2002 Regular Report on Slovakia's Progress towards Accession. SEC(2002) 1410.

European Commission (2008a). Report from the Commission to the European Parliament and the Council on Progress in Bulgaria under the Co-operation and Verification Mechanism. $\operatorname{COM}(2008) 495$ final.

European Commission (2008b). Report from the Commission to the European Parliament and the Council on Progress in Romania under the Co-operation and Verification Mechanism. $\operatorname{COM}(2008) 494$ final.

European Commission (2009a). Report from the Commission to the European Parliament and the Council on Progress in Bulgaria under the Co-operation and Verification Mechanism. COM(2009) 69 final.

European Commission (2009b). Report from the Commission to the European Parliament and the Council on Progress in Romania under the Co-operation and Verification Mechanism. COM(2009) 70 final.

European Parliament (1997). Resolution on the Communication from the Commission 'Agenda 2000 - for a stronger and wider Union' (COM(97)2000 - C4-0371/97), 4 December 1997.

FOCUS (2004), 'Percepcia Korupcie. Prieskum verejnej mienky pre Transparency International Slovensko', ('The Perception of Corruption. Survey of public opinion for Transparency International Slovakia'). Available at: http://www.transparency.sk/prieskumy/040623_perce.pdf, last accessed 6 April 2009.

Grabbe, H. (2001). 'How does Europeanization affect CEE governance? Conditionality, diffusion and diversity', Journal of European Public Policy, 8 (6), pp. 1013-1031.

Grabbe, H. (2006a). The EU's transformative Power. Europeanization through Conditionality in Central and Eastern Europe. Basingstoke: Palgrave Macmillan.

Grabbe, H. (2006b). 'Fighting Corruption. Patterns in Eastern Europe and in Central Asia.', European Policy Centre, Communication to Members, $N^{\circ}$ S45/06.

Grigorescu, A. (2006). 'The Corruption Eruption in East-Central Europe: The Increased Salience of Corruption and the Role of Intergovernmental Organisations', East European Politics and Societies, 20 (3), pp. 516-549.

Hodess, R. (ed) (2001). Global Corruption Report. Berlin: Transparency International.

Horáková, P. (2005). 'Former PM Stanislav Gross Bows Out of Politics', Radio Praha (26 September 2005). Available at: http://www.radio.cz/en/article/71044, last accessed 6 April 2009.

Johnston, M. (1986). 'The Political Consequences of Corruption: A Reassessment', Comparative Politics, 18 (3), pp. 459-477.

Johnston, M. (2000). 'Corruption and Democratic Consolidation', paper prepared for the Conference on Democracy and Corruption, Shelby Cullom Davis Center for Historical Studies, Princeton University, March 12, 1999 (revised June 2000).

Kaldor, M. and I. Vejvoda (1997). 'Democratization in central and east European countries', International Affairs, 73 (1), pp. 59-82.

Kaufmann, D., A. Kraay and M. Mastruzzi (2008). 'Governance Matters VII: Aggregate and Individual Governance Indicators 1996-2007', World Bank Policy Research Working Paper, WPS4654. Available at: 
http://papers.ssrn.com/sol3/papers.cfm?abstract id=1148386, last accessed 6 April 2009.

Krastev, I. (2004a). 'When 'should' does not imply 'can': The Making of the Washington Consensus on Corruption', in Shifting Obsessions: Three Essays on the Politics of Anti-Corruption. Budapest: Central European University Press, pp. 1-42.

Krastev, I. (2004b). Shifting Obsessions: Three Essays on the Politics of Anti-Corruption. Budapest: Central European University Press.

Lederman, D., N. Loayza and R. Reis Soares (2001). 'Accountability and Corruption. Political Institutions Matter', World Bank Policy Research Working Paper No. Available at: 2708 , http://papers.ssrn.com/sol3/papers.cfm?abstract_id=632777, last accessed 6 April 2009.

Linz, J. and A. Stepan (1996). Problems of democratic transition and consolidation: Soutern Europe, South America, and post-communist Europe. Baltimore: John Hopkins University Press.

Lízal, L. and E. Kočenda (2000). 'Corruption and Anticorruption in the Czech Republic', William Davidson Institute Working Paper No. 345. Available at: http://wdi.umich.edu/files/Publications/WorkingPapers/wp345.pdf, last accessed 6 April 2009.

Lízal, L. and E. Kočenda (2001). 'State of corruption in transition: case of the Czech Republic', Emerging Markets Review, 2, pp. 137-159.

Malová, D. (1997). 'Slovakia', European Journal of Political Research, 32 (3-4), pp. 481-488.

Malová, D. and P. Učen (2007). 'Slovakia', European Journal of Political Research, 46 (7-8), pp. 1096-1106.

Mamedova, L. (2002). 'Do Transitions Have To Be Corrupt? A Case Study of Slovakia', paper presented at the $6^{\text {th }}$ Symposium on Global Issues in Public Administration, Maxwell School of Syracuse University NY.

Olsen, J. (2002). 'The many faces of Europeanization', Journal of Common Market Studies, 40 (5), pp. 921-52.

Open Society Institute (2002). 'Monitoring the EU Accession Process: Corruption and anti-Corruption Policy', report consulted on 15 June 2007. Available at: http://www.eumap.org/reports/2002/corruption, last accessed 6 April 2009.

Orbie, J. (ed.) (2008). Europe's Global Role: External Policies of the European Union. Aldershot: Ashgate.

Pridham, G. (2002). 'EU Enlargement and Consolidating Democracy in Post-Communist States - Formality and Reality', Journal of Common Market Studies, 40 (3), 953973.

Pridham, G. (2006). 'EU Accession Dynamics and Democratisation in Central and Eastern Europe: Past and Future Perspectives', Government and Opposition, 41 (3), pp. 373-400.

Richter, J. (2007). 'Charges against Deputy Prime Minister jiri Cunek dropped, questions remain', Radio Praha. Available at: http://www.radiopraha.eu/en/article/94181, last accessed 6 April 2009.

Schedler, A., L. Diamond and M. F. Plattner (eds) (1999). The Self-Restraining State: Power and Accountability in New Democracies. Boulder: Rienner.

Schimmelfennig, F. and U. Sedelmeier (2004). 'Governance by conditionality: EU rule transfer to the candidate countries of Central and Eastern Europe', Journal of European Public Policy, 11 (4), pp. 661-679.

Schimmelfennig, F. and U. Sedelmeier (2005a). 'Introduction: Conceptualizing the Europeanization of Central and Eastern Europe' in F. Schimmelfennig and U. Sedelmeier (eds), The Europeanization of Central and Eastern Europe. Ithaka (N.Y.): Cornell University Press.

Schimmelfennig, F. and U. Sedelmeier (eds) (2005b). The Europeanization of Central and Eastern Europe. Ithaka (N.Y.): Cornell University Press.

Smith, K. (2004). The making of EU foreign policy: the case of Eastern Europe. Basingstoke: Palgrave Macmillan.

Tanzi, V. and H. Davoodi (1997). 'Corruption, Public Investment, and Growth', IMF Working Paper No. 97/139. Available at: 
http://papers.ssrn.com/sol3/papers.cfm?abstract id=882701, last accessed 6 April 2009.

Transparency International (2007). 'Corruption Perception Index', website consulted on 10 October 2007. Available at: http://www.transparency.org, last accessed 6 April 2009.

Učen, P. (2002). 'Slovakia', European Journal of Political Research, 41 (7-8), 1075-1083.

Vachudová, M. (2001). 'The Leverage of International Institutions on Democratizing States: Eastern Europe and the EU', EUI Working Papers, RSC No. 2001/33.

World Bank (2008a). 'Worldwide Governance Indicators, 1996-2007. Country Data Report for Czech Republic'. Available at:

http://info.worldbank.org/governance/wgi/pdf/c57.pdf, last accessed 6 April 2009.

World Bank (2008b). 'Worldwide Governance Indicators, 1996-2007. Country Data Report for Slovak Republic'. Available at:

http://info.worldbank.org/governance/wgi/pdf/c204.pdf, last accessed 6 April 2009. 